\title{
EFFECT OF USING COLOR LIGHT EMITTING DIODEON SOME PHYSIOLOGICAL PARAMETERS IN TWO STRAINS OF BROILERS
}

\author{
F. H. Abdou, A. A. EL-Fiky, E. M. Abou-Elewa and A. T. A. Mahmoud \\ Dept. of Poultry and Fish Production, Faculty of Agric., Menoufia Univ., Egypt.
}

Received: Feb. 2 , 2021

Accepted: Mar. 29,2021

\begin{abstract}
The present study investigated the broiler production under different LED light colors and strains. In addition, studying effect of LED light color on body weights at different ages, feed consumption (FC), immunity, growth hormone and some carcass traits. The experiment was extended from January 2019 to February 2019. The highest mean value was recorded for IR strain body weight at 7 days of age $(172.4 \pm 0.60,172.2 \pm$ 0.9 and $169.94 \pm 0.99 \mathrm{~g}$ ) in green, blue and white light, respectively. But for Cobb strain $(169.42 \pm 1.03,167.22 \pm 1.04$ and $168.028 \pm 0.83 \mathrm{~g})$ in green, white and blue light, respectively. Where, body weight at 35 days of age was recorded for Cobb and IR strains at blue light $(2002.17 \pm 12.81 \mathrm{~g})$ and $(2083.51 \pm 19.61 \mathrm{~g})$, respectively, followed by white light $(1985.22 \mathrm{~g})$ and $(2001.91 \pm 16.30 \mathrm{~g})$, respectively, while green light registered the least value $(1980.68 \mathrm{~g})$ and $(2001.82 \pm 10.66 \mathrm{~g})$, respectively. There were significant differences $(P \leq 0.05)$ in the values of growth hormone concentrations between control group (white light) and other two lights groups blue and green, on other hand, there were no significant differences in the values of growth hormone concentrations between Cobb and IR strains, the interaction between LED colors and strains was insignificant $(P=$ 0.982).
\end{abstract}

Key words: LED light color, productive, physiological traits, broilers.

\section{INTRODUCTION}

Lighting is a powerful exogenous factor in control of many physiological and behavioral processes. Light is integral to sight, including both visual acuity and color discrimination. Light allows the bird to establish rhythmicity and synchronize many essential functions, including body temperature and various metabolic steps that facilitate feeding and digestion. Of equal importance, light stimulates secretory patterns of several hormones that control, in large part, growth, maturation, and reproduction. (Olanrewaju, et al., 2018), light is considered one of the most managerial factors affecting poultry wellbeing. Therefore, the current study was conducted to investigate the effects of different light colors on performance of broilers (Hesham, et al., 2018).
Mudhar (2016a), found that significant effect $(P \leq 0.05)$ for the color light on the number of WBC in layers and recorded the highest rate $18.42 \times 10^{6} / \mathrm{ml}$ in the blood of chickens reared under the influence of WL. The other parameters of blood (PLT, Hb and PCV) showed no significant differences even for heterophil / lymphocyte ratio (H/L ratio).

Mudhar (2016b), found that significant effects were recorded on serum total protein and albumin of broilers under blue - green light (BGL), globulin under green light (GL) uric acid under blue light $(B L)$ and triglyceride under GL. For layers, the results showed a significant effect on glucose, globulin and HDL under white light (WL), total protein under BL. cholesterol under BGL and LDL under RL. The present study concluded that there was an advantage in the use of BGL and partially WL more 
than RL which increased the LDL level. Research needs to be conducted to investigate these traits. Broiler and layer welfare is increasingly becoming important to consumers who prefer that birds are raised in improved and comfortable conditions.

Wang, et al., (2016), found that The GH levels at different ages were similar among groups except for the GH value, which was lower in the blue light group at $14 \mathrm{~d}$ of age $(P=0.05)$. At $14 \mathrm{~d}$ of age, the IGF-1 level was higher in the white light group ( $P=0.036$ ), but at 21 and $28 \mathrm{~d}$ of age, the red light group had a higher IGF1 levels ( $P=0.05, P=0.003$, respectively). At $28 \mathrm{~d}$ of age, the blue light group had the lowest IGF-1 concentration ( $P=$ 0.011 ). The poultry industry has made improvements in broiler growth efficiency, including genetics, nutrition, and changes in environmental management resulting in more rapid broiler growth. However, to maximize the genetic potential of modern heavy-weight broilers, recommendations for environmental factors (light, air, temperature, humidity) are important to optimize profitability and minimize physiological stress of broilers (Olanrewaju, et al,. 2018).

In poultry farming, the light is determined to have crucial functions to carry out rhythmic and synchronized functions including important metabolic process of the body. Also, to control body temperature, and activities such as feed consumption, growth, maturity, and reproduction, as well as releasing, stimulating, and controlling hormones. While conventional incandescent and fluorescent lamps have been used as the source of light until the recent past, there have been technological advancements in illumination in the last few years and these lamps have started to be substituted with light emitting diodes (LED). The most important advantages of
LEDs are that they have high energy saving (consumption of energy of $80 \%$ lesser compared to incandescent lamp, $50 \%$ lesser compared to fluorescent lamp), are long-lasting, have high reliability, low costs of maintenance and the wavelength to ensure sufficient light stimulation for poultry species, (Simsek, et al., 2020).

Therefore, the present study investigates determination of the effect of LED light colors on some physiological and productive traits in two (Cobb and IR) broiler strains.

\section{MATERIALS AND METHODS}

The current study was conducted in private farm. The experiment was extended from January 2019 to December 2019.

\section{Experimental design:}

All birds were fed the basal starter, (1 14 days of age, with $23 \%$ crude protein and $3030 \mathrm{ME} \mathrm{kcal} / \mathrm{kg} \mathrm{diet),} \mathrm{grower} \mathrm{(14} \mathrm{-} 28$ days of age, with $21 \%$ crude protein and $3100 \mathrm{ME} \mathrm{kcal} / \mathrm{kg}$ ), and finisher (28 - 35 days of age, with $19 \%$ crude protein and $3200 \mathrm{ME} \mathrm{kcal} / \mathrm{kg}$ ), according to NRC (1994), feed and water were provided daily and ad libitum, as given in Table (1).

\section{LED}

\section{Light colors:}

Under both strains, birds allocated into three treatments: white LED light lamp as control $(900 \mathrm{~K})$, green LED light lamp $(900 \mathrm{~K})$ and blue LED light lamp (900 K). Artificial light was the only light source in the rearing rooms. The light source was placed $150 \mathrm{~cm}$ above the chicks. The electric power of the LED light was measured as 12 Watt.

Three LED light colors was used in the present study for each group (35 birds) on floor area $\left(3.5 \mathrm{~m}^{2}\right)$ for 24 hours. 
Table (1): Composition and calculated chemical analysis of experimental diets.

\begin{tabular}{|l|c|c|c|}
\hline Ingredients & $\begin{array}{c}\text { Starter } \\
\text { period } \\
(1-14 \text { day })\end{array}$ & $\begin{array}{c}\text { Grower period } \\
(14-28 \text { day })\end{array}$ & $\begin{array}{c}\text { Finisher period } \\
(28-35 \text { days })\end{array}$ \\
\hline Ground yellow corn (8.5\%). & 541 & 592.0 & 656.7 \\
\hline Soybean meal, (44\%). & 320 & 260 & 190 \\
\hline Full fat soya. & 29 & 29 & 30 \\
\hline Glutein, (60\%). & 71.5 & 78.0 & 84.9 \\
\hline Mono calcium phosphate. & 16.6 & 17.5 & 15.3 \\
\hline Limestone. & 13 & 13.4 & 11.8 \\
\hline L-lysine. & 1 & 2 & 3 \\
\hline DL-methionine. & 1.2 & 1.4 & 1.6 \\
\hline Salt (NaCl). & 3.7 & 3.7 & 3.7 \\
\hline Premix (Minerals and Vitamins) ${ }^{(1)}$. & 3 & 3 & 3 \\
\hline Total (kg). & 1000 & 1000 & 1000 \\
\hline Calculated chemical composition ${ }^{(2)}$ & \multicolumn{3}{|l|}{} \\
\hline Crude protein, \%. & 23 & 21 & 19 \\
\hline ME (kcal/kg). & 3030 & 3100 & 3200 \\
\hline Crude fiber, \%. & 3.77 & 3.41 & 3.06 \\
\hline Raw fat is not less than, \%. & 5.56 & 5.7 & 5.96 \\
\hline
\end{tabular}

${ }^{(1)}$ Premix. at $0.30 \%$ of the diet supplies the following/ $\mathrm{kg}$ of the diet: Vit. A, $12000 \mathrm{lU}$;Vit.E, $10 \mathrm{mg}$; Vit. $K_{3}, 3 \mathrm{mg}$; Vit $B_{1}, 1 \mathrm{mg}$; Vit. $B_{2}, 4 \mathrm{mg}$; Pantothenic acid, $10 \mathrm{mg}$;Vit. $D_{3}, 2500 \mathrm{IU}$; Nicotinic acid, $20 \mathrm{mg}$; Folic acid, $1 \mathrm{mg}$; Biotin, $0.05 \mathrm{mg}$; Niacin, $40 \mathrm{mg}$; Vit. ${ }_{6}, 3 \mathrm{mg}$; Vit $B_{12}, 0.02 \mathrm{mg}$; Choline chloride, $400 \mathrm{mg}$; Mn, $62 \mathrm{mg}$; Fe, $44 \mathrm{mg}$; Zn, $56 \mathrm{mg}$; I, $1 \mathrm{mg}$; Cu, $5 \mathrm{mg}$ and Se, $0.01 \mathrm{mg}$.

${ }^{(2)}$ Calculated according to NRC (1994).

\section{Determination of antibody response}

The primary antibody titers to SRBCs were determined for all individuals $(n=$ 35 ) at 5 weeks of age, as the following steps:

\subsection{Preparation of sheep red blood cells antigen:}

The SRBC were obtained in a heparin solution from Ossimi sheep breed and washed three times in phosphate buffer saline (PBS, pH. 7.2). After final wash, the packed SRBC were brought to a $2.5 \%$ Vo/Vo solution in the PBS and used for immunization.

\subsection{Antigen immunization:}

The SRBC antigen was immunized using a slight modification in the method of Siegel and Gross (1980). At 5 weeks of age, the primary antibody response was determined for each individual at 7 days post immunization. Each chicken was received an intravenous immunization via the branchial vein with $0.1 \mathrm{ml}$ of $2.5 \%$ SRBC suspension to induce the primary antibody response.

\subsection{Growth hormone determination:}

The Access Ultrasensitive GH assay is a simultaneous one-step 
immunoenzymatic ("sandwich") assay. A sample is added to a reaction vessel along with polyclonal goat anti-hGH alkaline phosphatase conjugate, and paramagnetic particles coated with mouse monoclonal anti-hGH antibody. The serum or plasma (heparin) hGH binds to the monoclonal anti-hGH on the solid phase, while the goat anti-hGHalkaline hosphatase conjugate reacts with a different antigenic site on the serum or plasma hGH. After incubation in a reaction vessel, materials bound to the solid phase are held in a magnetic field while unbound materials are washed away. Then, the chemiluminescent substrate is added to the vessel and light generated by the reaction is measured with a luminometer. The light production is directly proportional to the concentration of hGH in the sample. The amount of analyte in the sample is determined from a stored, multi-point calibration curve (Iranmanesh, et al., 1994).

\subsection{Blood samples collection and serum preparation:}

At the end of 5 wk, 2 birds of average weight from each replicate were treated and blood was collected from the wing. The hematological analysis was performed by using Hemavet 950 (Drew Scientific Inc., Waterbury, CT) immediately after collection of the blood. The hematological analysis includes red blood cells (RBC), white blood cells (WBC), hematocrit (Hct), and platelet count. According to Kim, et al. (2013).

\subsection{Titration and calculation of antibody titers:}

The antibody in chickens blood sera were determined by the microtiter method of hemagglutinin test assay described by Siegel and Gross (1980). Serum samples were titrated individually in 96- well (eight rows by 12 columns, round (U) bottom) assay plates. Only, $50 \mu$ l of physiological saline $(0.9 \% \mathrm{NaCl})$ was added to all 96 well plates followed with $50 \mu \mathrm{l}$ of serum sample to first well (row 1). Serial dilutions of each serum sample were then made from the first through the eleventh wells. This step results in dilutions ranging from $1: 1$ to $1: 1024$. Well number 12 was used as the control. Next, $50 \mu \mathrm{l}$ of $2.0 \%$ packed SRBC solution was added to each well. The 96-well plates were then covered, mixed and incubated at $37{ }^{\circ} \mathrm{C}$ for about one hour. Then, both variables, positive and negative hemagglutination, were recorded. Antibody titers were expressed as the $\log _{2}$ of the reciprocal of the last serum dilution, in which there was positive complete hemagglutination.

Table (2): The experimental design and the number of samples used for antibody titer.

\begin{tabular}{|c|c|c|}
\hline Character & Age & No. of samples \\
\hline Determination of antibody titer. & $5-w k$ & 35 \\
\hline \multirow{3}{*}{ Determination of body weight. } & 1 -wk & 35 \\
\cline { 2 - 3 } & $2-w k$ & 35 \\
\cline { 2 - 3 } & $3-w k$ & 35 \\
\cline { 2 - 3 } & $4-w k$ & 35 \\
\cline { 2 - 3 } & 5 -wk & 35 \\
\hline & Marketing age & 35 \\
\hline
\end{tabular}




\section{The studied traits:}

\subsection{Body weights at different ages:}

Weekly body weights were measured at one day old chicks, then were weighted weekly till 35 days. Each week sample was taken randomly and weighted to estimate average body weight of the dormitories and this samples were applied in all commercial broiler farms.

\subsection{Feed consumption (FC) (kg per bird/cycle) and feed conversion ratio (FCR):}

The amount of feed consumption per bird per cycle were calculated by dividing the total feed intake during the cycle on the receiving bird numbers in each dormitories.

The feed conversion ratio was calculated as follow:

$$
F C R=\frac{\text { The feed consumption }(\mathrm{kg}) / \mathrm{bird} / \text { cycle }}{\text { Body weight gain /brid/cycle }(\mathrm{kg})}
$$

While body weight gain was measured as deviation between the body weights (in gram) at marketing ages.

\section{Carcass traits:}

At the end of the experimental (5 weeks of age), 5 birds from each treatment around the average preslaughter weight were chosen, fasted for about 12 hours, weighed and slaughtered to complete bleeding, followed by plucking the feathers. Blood, feather, intestinal, eaten innards, eviscerated weight and dressing percentages were expressed related to live body weight were recorded.

$$
\text { Dressing percentages }=\frac{\text { Eviscerated weight }}{\text { Pre }- \text { slaughter weight }} \times 100
$$

\section{Statistical analysis:}

Data were computerized and analyzed according to the following model by SPSS Program (2004). Also, significant differences among means were detected by Duncan (1955).

$Y_{i j k}=\mu+S_{i}+D_{j}+(S \times D)_{i j}+e_{i j k}$

Where:

$Y_{i j k} \quad$ : Observation of $i$ strain, and $j$ LED light color;

$\mu \quad$ : General mean;

$S_{i} \quad$ : Fixed effect of strain;

$D_{j} \quad$ : Fixed effect of $\left(D_{j}\right)$ LED light color;

$(S \times D)_{i j}$ : Effect of interaction $(S \times D)_{i j}$;

$e_{i j k} \quad$ : Residual effect.

\section{RESULTS AND DISCUSSION}

\section{Effect of light color on body weight:}

The obtained results in Table (3) showed the body weights in different groups of light colors (white as control, blue and green) for Cobb and IR chicken strains at $(7,14,21,28$ and 35$)$ days of age.

The obtained results in Table (3) showed the body weights in different groups of light colors (white as control, blue and green) for Cobb and IR chicken strains at 7 days of age.

The statistical analysis of the data in Table (3) revealed that there were no significant differences in weights between control group and other two lights groups blue and green. On other hand, there were significant differences $(P \leq 0.01)$ in the values of body weights between Cobb and IR strains at 35 days of age.

Data in Table (3) revealed that the effect of interaction between LED color and strain was insignificant $(P=0.244)$, and there were no significant differences in body weights between control group for white light and other two lights groups blue and green, on other hand, there were significant differences $(P \leq$ 0.01) in the values of body weights between Cobb and IR strains at 7 days of age. 
Table (3): Body weight $(\mathrm{g})$ as affected by light color and strains at different ages $(7,14,28$ and $35 \mathrm{~d}$. of age).

\begin{tabular}{|c|c|c|c|c|c|c|c|}
\hline \multirow[t]{2}{*}{ Strain } & \multirow{2}{*}{$\begin{array}{l}\text { Light } \\
\text { color }\end{array}$} & \multirow{2}{*}{ No. } & \multicolumn{5}{|c|}{ Mean \pm S.E. } \\
\hline & & & at $7 \mathrm{~d}$. & at $14 \mathrm{~d}$. & at $21 \mathrm{~d}$. & at $28 \mathrm{~d}$. & at $35 \mathrm{~d}$. \\
\hline \multirow{3}{*}{ Cobb } & Green & 35 & $169.42 \pm 1.03^{a}$ & $436.6 \pm 3.60^{a}$ & $842.91 \pm 2.78^{a}$ & $1391.6 \pm 1.66 \mathrm{a}^{\mathrm{b}}$ & $1980.68 \pm 10.24^{b}$ \\
\hline & Blue & 35 & $167.22 \pm 1.04^{\mathrm{ab}}$ & $433.85 \pm 12.33^{a}$ & $823.71 \pm 5.72^{b}$ & $1397.57 \pm 2.89^{a}$ & $2002.17 \pm 12.81^{a}$ \\
\hline & White & 35 & $168.028 \pm 0.83^{b}$ & $417.48 \pm 2.93^{b}$ & $815.42 \pm 5.78^{b}$ & $1370.02 \pm 6.53^{b}$ & $1985.22 \pm 8.64^{b}$ \\
\hline \multirow{3}{*}{ IR } & Green & 35 & $172.4 \pm 0.60^{\mathrm{a}}$ & $447.17 \pm 3.09^{a}$ & $933.86 \pm 3.09^{a}$ & $1402.77 \pm 2.60^{b}$ & $2001.82 \pm 10.66^{b}$ \\
\hline & Blue & 35 & $172.2 \pm 0.96^{\mathrm{ab}}$ & $447.45 \pm 5.20^{\mathrm{a}}$ & $932.97 \pm 4.43^{b}$ & $1419.45 \pm 5.13^{a}$ & $2083.51 \pm 19.61^{a}$ \\
\hline & White & 35 & $169.94 \pm 0.99^{b}$ & $439.2 \pm 3.47^{b}$ & $928.05 \pm 4.37^{b}$ & $1404.97 \pm 7.80^{\mathrm{ab}}$ & $2001.91 \pm 16.30^{b}$ \\
\hline \multicolumn{8}{|c|}{ ANOVA } \\
\hline Strain (S) & \multicolumn{2}{|c|}{ P-Value } & $0.001^{\star *}$ & $0.002^{\star \star}$ & $0.001^{\star *}$ & $0.001^{\star \star}$ & $0.001^{\star \star}$ \\
\hline $\begin{array}{c}\text { Light } \\
\text { colors(C) }\end{array}$ & \multicolumn{2}{|c|}{ P-Value } & 0.101 n.s & $0.050^{\star}$ & $0.001^{\star *}$ & $0.039^{\star}$ & $0.001^{\star *}$ \\
\hline$S \times C$ & \multicolumn{2}{|c|}{ P-Value } & 0.244 n.s & 0.639 n.s & $0.037^{\star}$ & 0.350 n.s & $0.031^{*}$ \\
\hline
\end{tabular}

a, b, c,: Means in the same column bearing different superscripts are significantly different .

** Significant differences at $P \leq 0.01$.

* Significant differences at $P \leq 0.05$.

n.s. not significant

The highest mean value was recorded for Cobb strain in green light (GL) (169.42 $\pm 1.03 \mathrm{~g}$ ), followed control group (167.22 $\pm 1.04 \mathrm{~g}$ ), while blue light (BL) registered the least value $(168.028 \pm 0.83 \mathrm{~g})$. Results indicated that the body weight in green light was increased by $0.83 \%$ compared to white light group, while it was decreased compared to white light decreased by $0.48 \%$ at blue light.

However, the highest mean value was recorded for IR strain in green light (GL) $(172.4 \pm 0.60 \mathrm{~g})$, followed by blue light (BL) $(172.2 \pm 0.9 \mathrm{~g})$, while white light (WL) registered the least value $(169.94 \pm 0.99$ g). Results indicated that the body weight in green light was increased by $1.48 \%$ compared to the control group, while it was $1.33 \%$ in blue light.

Results were in agreement with those found by Kim, et al. (2013) for body weight at 7 days of age, where green, blue and white LED color reached the weight of $(165 \pm 8,170 \pm 3$ and $162 \pm 3 g)$, respectively.

The highest mean value was recorded for Cobb and IR strains in blue light $(2002.17 \pm 12.81 \mathrm{~g})$ and $(2083.51 \pm 19.61$ g), respectively, followed by white light $(1985.22 \mathrm{~g})$ and $(2001.91 \pm 16.30 \mathrm{~g})$, respectively, while green light registered the least value $(1980.68 \mathrm{~g})$ and $(2001.82 \pm$ $10.66 \mathrm{~g}$ ), respectively.

Results indicated that Cobb strain body weight in blue light was increased by $0.85 \%$ compared to white light group, while it was decreased by $0.23 \%$ in green light. But, IR strain body weight in blue light was increased by $4.08 \%$ compared to white light group, while it was the same in green light.

Table (3) cleared that there was a significant $(P \leq 0.05)$ interaction between strains and light colors. This was mainly 
due to the big differences between blue and other light treatments especially in IR strain. This may lead to the conclusion that blue color is more profitable to be used in IR breed.

The obtained results were in agreement with the results obtained by Khaliq, et al. (2017), they found significant differences in body weight in the $6^{\text {th }}$ week with birds reared under blue light having highest body weight of $1593.20 \pm 7.45 \mathrm{~g}$ followed by $1541.76 \pm$ $4.28 \mathrm{~g}$ in birds reared under (Control), $1530.58 \pm 25.03 \mathrm{~g}$ in group reared under red light and $1470.23 \pm 6.40 \mathrm{~g}$ in birds reared under green light.

These results were in opposite with those obtained by (Cao, et al., 2012), who found that there was no adverse effect of LED lights color on final body weight. (Borille, et al., 2013) was also resembled that LED lights color have no effects on poultry growth performance.

\section{Effect of light colors and strains on feed consumption:}

The obtained results in Table (4) showed the feed consumption in different groups of light colors (white as control, blue and green) for Cobb and IR chicken strains at $\left(1^{\text {st, }} 2^{\text {nd }}, 3^{\text {rd }}, 4^{\text {th }}\right.$ and $5^{\text {th }}$ wk. $)$ of age.

The results in the body weights in control and treated groups of different light colors (white as control, blue and green) for Cobb and IR chicken strains at $1^{\text {st }}$ week of age. Data in Table (4) revealed that there were highly significant differences $(P \leq 0.01)$ in feed consumption $(g)$ between control group and other two lights groups blue and green. On other hand, there were highly significant differences $(P \leq 0.01)$ in the values of feed consumption between Cobb and IR strains at $1^{\text {st }}$ week of age.

The highest mean value was recorded for Cobb strain $(222.86 \pm 0.13 \mathrm{~g})$ that was consumed under green light, followed by blue light $(221.43 \pm 0.13 \mathrm{~g})$, while white light as control group registered the least value $(220.00 \pm 0.13 \mathrm{~g})$. Results indicated that the feed consumption in green light was increased by $1.30 \%$ compared to white light group, while it was $0.65 \%$ in blue light.

However, the mean value was recorded for IR strain in green light, blue light, while white light registered the same value $(228.57 \pm 0.13 \mathrm{~g})$.

Results were in agreement with the results obtained by Kim, et al. (2013), they found that, feed consumption were $(183 \pm 4,177 \pm 6$ and $177 \pm 1 \mathrm{~g})$ for LED light (blue, green and white), respectively.

Finally, data in Table (4) revealed that there were highly significant differences $(P \leq 0.01)$ in the values of feed consumption between control group and other two lights groups blue and green, there were highly significant differences $(P \leq 0.01)$ in the values of feed consumption between Cobb and IR strains at $5^{\text {th }}$ week of age.

The highest mean value was recorded for Cobb strain in blue light $(945.71 \pm 0.55$ g), followed by white light $(942.86 \pm 0.55$ g), while green light registered the least value $(934.29 \pm 0.55 \mathrm{~g})$. Results indicated that the feed consumption in blue light was increased by $\mathbf{0 . 3 0} \%$ compared to white light as control group, while it was decreased by $0.91 \%$ in green light.

However, the highest mean value was recorded for IR strain in white light $(986.57 \pm 0.55 \mathrm{~g})$, followed by green light $(980.00 \pm 0.55 \mathrm{~g})$, while blue light registered the least value $(971.43 \pm 0.55 \mathrm{~g})$. Results indicated that the feed consumption in both of green and blue light were decreased by $0.67 \%$ and 1.53 $\%$, respectively, compared to white light group. 
Table (4): Feed consumption ( $\mathrm{g}$ ) as affected by light color and strains at different ages $\left(1^{\text {st, }} 2^{\text {nd }}, 3^{\text {rd }}, 4^{\text {th }}\right.$ and $5^{\text {th }}$ wk. of age. $)$

\begin{tabular}{|c|c|c|c|c|c|c|c|}
\hline \multirow[t]{2}{*}{ Strain } & \multirow{2}{*}{$\begin{array}{l}\text { Light } \\
\text { color }\end{array}$} & \multirow{2}{*}{ No. } & \multicolumn{5}{|c|}{ Mean \pm SE } \\
\hline & & & $1^{\text {st }} \mathrm{wk}$. & $2^{\text {nd }} w k$. & $3^{\text {rd }}$ wk. & $4^{\text {th }} w k$. & $5^{\text {th }} \mathrm{wk}$. \\
\hline \multirow{3}{*}{ Cobb } & Green & 5 & $222.86 \pm 0.13^{a}$ & $408.57 \pm 0.236^{b}$ & $614.29 \pm 0.356^{a}$ & $857.14 \pm 0.508^{c}$ & $934.29 \pm 0.55 b$ \\
\hline & Blue & 5 & $221.43 \pm 0.13^{b}$ & $414.29 \pm 0.236^{\mathrm{a}}$ & $602.86 \pm 0.356^{b}$ & $871.43 \pm 0.508^{a}$ & $945.71 \pm 0.55 a$ \\
\hline & White & 5 & $220.00 \pm 0.13^{c}$ & $404.29 \pm 0.236^{\mathrm{b}}$ & $601.43 \pm 0.356^{b}$ & $865.71 \pm 0.508^{b}$ & $942.86 \pm 0.55 a$ \\
\hline \multirow{3}{*}{ IR } & Green & 5 & $228.57 \pm 0.13$ & $414.29 \pm 0.236^{\mathrm{a}}$ & $628.57 \pm 0.356^{\mathrm{ab}}$ & $894.29 \pm 0.508^{b}$ & $980.00 \pm 0.55 b$ \\
\hline & Blue & 5 & $228.57 \pm 0.13$ & $408.57 \pm 0.236^{b}$ & $617.14 \pm 0.356^{b}$ & $885.71 \pm 0.508^{c}$ & $971.43 \pm 0.55 c$ \\
\hline & White & 5 & $228.57 \pm 0.13$ & $401.71 \pm 0.236^{c}$ & $632.86 \pm 0.356^{a}$ & $902.86 \pm 0.508^{a}$ & $986.57 \pm 0.55 a$ \\
\hline \multicolumn{8}{|c|}{ ANOVA } \\
\hline $\begin{array}{l}\text { Strains } \\
\text { (S) }\end{array}$ & \multicolumn{2}{|c|}{ P-Value } & $0.000^{\star \star}$ & $0.000^{\star \star}$ & $0.000^{\star \star}$ & $0.000^{\star \star}$ & $0.000^{\star *}$ \\
\hline $\begin{array}{l}\text { Light } \\
\text { colors(C) }\end{array}$ & \multicolumn{2}{|l|}{ P-Value } & $0.000^{\star \star}$ & $0.000^{\star \star}$ & $0.000^{\star \star}$ & $0.000^{\star \star}$ & $0.000^{\star \star}$ \\
\hline $\mathrm{S} \times \mathrm{C}$ & \multicolumn{2}{|c|}{ P-Value } & $0.000^{\star \star}$ & $0.000^{\star *}$ & $0.000^{\star *}$ & $0.000^{\star *}$ & $0.000^{\star \star}$ \\
\hline
\end{tabular}

a, b, c, :Means in the same column bearing different superscripts are significantly different .

${ }^{* *}$ Significant differences at $\mathrm{P} \leq 0.01$.

It was cleared that there was a highly significant $(P \leq 0.01)$ interaction between strains and light colors (Table 4). This may be due to the disarrangement of the effect of color in both breeds. The explain of this interaction was due to mainly the different arrangement of color effects in both breeds. This was clear that blue color is more suitable in Cobb breed while white color was the suitable for IR breed.

Results were disagreement with the results obtained by Kim, et al. (2013), they found that, feed consumption were $(1831 \pm 56,1898 \pm 70$ and $1885 \pm 14 \mathrm{~g})$ for LED light (blue, green and white), respectively.

Yang, et al. (2016), Alattar, et al. (2019), and Simsek, et al. (2020), found significant differences between LED color for feed consumption.

\section{Effect of light colors and strains on feed conversion ratio:}

Results in Table (5) showed the feed conversion ratio in control and selected groups of different light colors (white as control, blue and green) for Cobb and IR chicken strains at $1^{\text {st }}$ week of age.

Data in Table (5) revealed that there were highly significant differences $(P \leq$ 0.01 ) in the values of feed conversion ratio between control group for white light and other two lights groups blue and green, on other hand, there were highly significant differences $(P \leq 0.01)$ in the values of feed consumption between Cobb and IR strains at $1^{\text {st }}$ week of age, the interaction between LED colors and strains was significant $(P \leq 0.01)$.

The worst mean value was recorded for Cobb strain $(1.32 \pm 0.05)$ in blue light trait, followed by green light $(1.315 \pm 0.05)$, while white light as control group registered the best value $(1.309 \pm 0.05)$. Results indicated that the feed conversion ratio in blue light was increased by $1.14 \%$ compared to white light group, while it was $0.47 \%$ in green light.

However, the worst mean value was recorded for IR strain $(1.345 \pm 0.05)$ in 
white light trait, followed by blue light (1.327 \pm 0.05$)$, while green group registered the best $(1.326 \pm 0.05)$. Results indicated that the feed conversion ratio in blue light was decreased by $1.31 \%$ compared to white light group (100\%), while it was $1.43 \%$ in green light.

Results were in agreement with the results obtained by Kim, et al. (2013), they found that, feed conversion ratio were $(1.08 \pm 0.01,1.08 \pm 0.02$ and $1.10 \pm$ 0.01) for LED light (blue, green and white), respectively.

Results in Table (5) showed the feed conversion ratio in control and other groups of different light colors (white as control, blue and green) for Cobb and IR chicken strains at $5^{\text {th }}$ week of age.

Data in Table (5) revealed that there were highly significant differences $(P \leq$ 0.05 ) in the values of feed conversion ratio between control group for white light and other two lights groups blue and green, on other hand, there were highly significant differences $(P \leq 0.05)$ in the values of feed consumption between Cobb and IR strains at $5^{\text {th }}$ week of age, the interaction between LED colors and strains was significant $(P \leq 0.05)$.

The worst mean value was recorded for Cobb strain $(1.533 \pm 0.04)$ in green light trait, followed by white light (1.528 \pm 0.04$)$, while blue light registered the best value (1.526 \pm 0.04$)$. Results indicated that the feed conversion ratio in green light was increased by $0.32 \%$ compared to white light group, while it was decreased by $0.15 \%$ in blue light.

However, The worst mean value was recorded for IR strain $(1.575 \pm 0.04)$ in white light trait, followed by green light

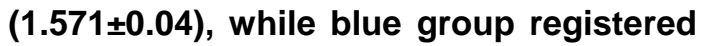

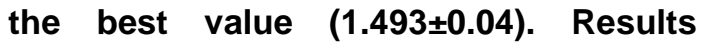
indicated that the feed conversion ratio in green light was decreased by $0.21 \%$ compared to white light group, while it was $5.17 \%$ in blue light.

Results were in agreement with the results obtained by Kim, et al. (2013), they found that, feed consumption were $(2.39 \pm 0.08,2.45 \pm 0.19$ and $2.50 \pm 0.20)$ for LED light (blue, green and white), respectively.

Table (5): Feed conversion ratio as affected by light color and strains at different ages $\left(1^{\text {st, }} 2^{\text {nd }}, 3^{\text {rd }}, 4^{\text {th }}\right.$ and $5^{\text {th }}$ wk. of age. $)$

\begin{tabular}{|c|c|c|c|c|c|c|c|}
\hline \multirow[t]{2}{*}{ Strain } & \multirow{2}{*}{$\begin{array}{l}\text { Light } \\
\text { color }\end{array}$} & \multirow{2}{*}{ No. } & \multicolumn{5}{|c|}{ Mean \pm SE } \\
\hline & & & $1^{\text {st }} \mathrm{wk}$. & $2^{\text {nd }} w k$. & $3^{\text {rd }}$ wk. & $4^{\text {th }}$ wk. & $5^{\text {th }}$ wk. \\
\hline \multirow{3}{*}{ Cobb } & Green & 5 & $1.315 \pm 0.05^{0}$ & $1.446 \pm 0.07^{c}$ & $1.478 \pm 0.064^{c}$ & $1.511 \pm 0.052^{D}$ & $1.533 \pm 0.04 a$ \\
\hline & Blue & 5 & $1.32 \pm 0.05^{a}$ & $1.465 \pm 0.07^{b}$ & $1.504 \pm 0.064^{a}$ & $1.510 \pm 0.052^{b}$ & $1.526 \pm 0.04 b$ \\
\hline & White & 5 & $1.309 \pm 0.05^{c}$ & $1.495 \pm 0.07^{a}$ & $1.503 \pm 0.064^{b}$ & $1.527 \pm 0.052^{a}$ & $1.528 \pm 0.04 b$ \\
\hline \multirow{3}{*}{ IR } & Green & 5 & $1.326 \pm 0.05^{b}$ & $1.438 \pm 0.07^{a}$ & $1.361 \pm 0.064^{a}$ & $1.544 \pm 0.052^{a}$ & $1.571 \pm 0.04 a$ \\
\hline & Blue & 5 & $1.327 \pm 0.05^{b}$ & $1.424 \pm 0.07^{b}$ & $1.344 \pm 0.064^{b}$ & $1.508 \pm 0.052^{b}$ & $1.493 \pm 0.04 b$ \\
\hline & White & 5 & $1.345 \pm 0.05^{a}$ & $1.435 \pm 0.07^{a}$ & $1.361 \pm 0.064^{a}$ & $1.542 \pm 0.052^{a}$ & $1.575 \pm 0.04 a$ \\
\hline \multicolumn{8}{|c|}{ ANOVA } \\
\hline \begin{tabular}{|l|} 
Strains \\
(S)
\end{tabular} & \multicolumn{2}{|l|}{ P-Value } & $0.000^{* \star}$ & $0.000^{\star \star}$ & $0.000^{\star *}$ & $0.048^{\star}$ & $0.028^{*}$ \\
\hline \begin{tabular}{|l|} 
Light \\
colors (C)
\end{tabular} & \multicolumn{2}{|l|}{ P-Value } & $0.000^{\star *}$ & $0.000^{* \star}$ & $0.035^{\star}$ & $0.044^{\star}$ & $0.035^{\star}$ \\
\hline $\mathrm{S} \times \mathrm{C}$ & \multicolumn{2}{|l|}{ P-Value } & $0.000^{\star *}$ & $0.015^{\star}$ & $0.021^{*}$ & $0.039^{*}$ & $0.017^{\star}$ \\
\hline
\end{tabular}

a, b, c,: Means in the same column bearing different superscripts are significantly different .

** Significant differences at $\mathbf{P} \leq 0.01$.

* Significant differences at $\mathrm{P} \leq \mathbf{0 . 0 5}$. 


\section{Effect of light colors and strains on antibody titer concentration:}

It is important to maintain immune function in broilers because poor immune status can decrease disease resistance leading to reduced productivity.

The obtained results in Table (6) showed the concentrations of antibody titer in control and treated groups of different light colors (white as control, blue and green) for Cobb and IR chicken strains.

Data Table (6) revealed that there were significant differences $(P \leq 0.05)$ in the values of antibody titer between control group and other two lights groups blue and green. On other hand, there were highly significant differences $(P \leq 0.01)$ in the values of antibody titer between Cobb and IR strains.

The highest mean value was recorded for Cobb strain in blue light (BL) $(3.48 \pm 0.45)$, followed by green light (GL) $(2.88 \pm 0.45)$, while control group (white light, $W L$ ) registered the least value $(1.8 \pm 0.37)$. Results indicated that the antibody titer concentration in blue light was increased by $93.33 \%$ compared to white light group, while it was $60.00 \%$ in green light.

Also, the highest mean value was recorded for IR strain in blue light (BL) (4.32 \pm 0.32$)$, followed by green light (GL) (3.48 \pm 0.45 ), while control group (white light, WL) registered the least value $(2.4 \pm 0.31)$. Results indicated that the antibody titer concentration in blue light was increased by $\mathbf{8 0 . 0 0} \%$ compared to white light group, while it was $45.00 \%$ in green light.

The superiority of blue light over green and white colors in the present study is consistent with the results of Xie, et al. (2008a) and Xie, et al. (2008b), suggested that green and blue light enhance broiler immune function; broilers reared under different blue and green LED colors, which could enable applying more diverse LED colors.

Table (6): Antibody titer concentrations (Mean \pm SE) in control and other groups of chicken strains and light colors.

\begin{tabular}{|l|c|c|c|}
\hline \multicolumn{1}{|c|}{ Strains } & Light colors & $\mathrm{n}$ & Mean \pm SE \\
\hline \multirow{3}{*}{ Cobb } & Green & 10 & $2.88 \pm 0.45^{\mathrm{a}}$ \\
\cline { 2 - 4 } & Blue & 10 & $3.48 \pm 0.45^{\mathrm{a}}$ \\
\cline { 2 - 4 } & White & 10 & $1.8 \pm 0.37^{\mathrm{b}}$ \\
\cline { 2 - 4 } & Green & 10 & $3.48 \pm 0.45^{\mathrm{a}}$ \\
\cline { 2 - 4 } & Blue & 10 & $4.32 \pm 0.32^{\mathrm{a}}$ \\
\cline { 2 - 4 } & White & 10 & $2.4 \pm 0.31^{\mathrm{b}}$ \\
\cline { 2 - 4 } & \multicolumn{2}{|c|}{ ANOVA } \\
\hline Strains (S) & P-Value & $0.041^{*}$ & \\
\hline Light colors (C) & P-Value & $0.001^{* *}$ & \\
\hline S×C & P-Value & $0.941 \mathrm{n} . \mathrm{s}$ & \\
\hline
\end{tabular}

a, b, c, :Means in the same column bearing different superscripts are significantly different .

** Significant differences at $P \leq 0.01$.

* Significant differences at $P \leq 0.05$.

n.s. not significant. 


\section{Effect of light color and strain on growth hormone concentrations ( $\mathrm{ng} / \mathrm{mL})$ :}

The obtained results in Table (7) showed the growth hormone concentrations in different light colors (white as control, blue and green) for Cobb and IR chicken strains.

The statistical analysis of the data Table (7) revealed that there were significant differences $(P \leq 0.05)$ in the values of growth hormone concentrations between control group (white light) and other two lights groups blue and green. On other hand, there were no significant differences in the values of growth hormone concentrations between Cobb and IR strains, the interaction between LED color and strains was insignificant $(P=$ 0.982).

The highest mean value was recorded for Cobb strain in blue light $(1.186 \pm 0.04$ $\mathrm{ng} / \mathrm{mL})$, followed by green light (0.968 $\pm 0.12 \mathrm{ng} / \mathrm{mL})$, while control group (white light, $W L$ ) registered the least value $(0.72 \pm 0.10 \mathrm{ng} / \mathrm{mL})$. Results indicated that the growth hormone concentrations at blue light was increased by $64.72 \%$ compared to white light group, while it was $34.44 \%$ in green light.

Also, the highest mean value was recorded for IR strain in blue light (1.2 $\pm 0.13 \mathrm{ng} / \mathrm{mL})$, followed by green light $(0.962 \pm 0.18 \mathrm{ng} / \mathrm{mL})$, while control group (white light, WL) registered the least value $(0.684 \pm 0.17 \mathrm{ng} / \mathrm{mL})$. Results indicated that the growth hormone concentrations in blue light was increased by $75.44 \%$ compared to white light as control group, while it was $40.64 \%$ in green light.

The results indicted that the effect on interaction between light color and strain on growth hormone was not significant.

Growth hormone receptor gene expression was also higher in the green and blue light, compared to white light group and higher muscle weight found in the green and blue light groups was due to increased satellite cell proliferation during the first days of age (Kumar, et al., 2019).

Results were in agreement with those reported by Kuhn, et al. (1996), Zang, et al. (2014) and Wang, et al. (2016).

Light stimulated secretor patterns several hormones that control growth, maturation and reproduction.

Table (7): Effect of light color and strain on growth hormone concentrations ( $\bar{X} \pm \mathrm{SE})$.

\begin{tabular}{|c|c|c|c|}
\hline Strains & Light colors & $\mathbf{n}$ & Mean \pm S.E. \\
\hline \multirow{3}{*}{ Cobb } & Green & 5 & $0.968 \pm 0.12^{\mathrm{ab}}$ \\
\hline & Blue & 5 & $1.186 \pm 0.04^{\mathrm{a}}$ \\
\hline & White & 5 & $0.72 \pm 0.10^{\mathrm{D}}$ \\
\hline \multirow{3}{*}{ IR } & Green & 5 & $0.962 \pm 0.18^{\mathrm{aD}}$ \\
\hline & Blue & 5 & $1.2 \pm 0.13^{\mathrm{a}}$ \\
\hline & White & 5 & $0.684 \pm 0.17^{b}$ \\
\hline \multicolumn{4}{|c|}{ ANOVA } \\
\hline Strains (S) & P-Value & $0.932 n . s$ & \\
\hline Light colors (C) & P-Value & $0.004^{\star \star}$ & \\
\hline$S \times C$ & P-Value & 0.982 n.s & \\
\hline
\end{tabular}

a, b, c, :Means in the same column bearing different superscripts are significantly different .

** Highly significant $(P \leq 0.01)$.

* significant $(P \leq 0.05)$.

n.s. not significant. 


\section{Effect of light color on some carcass traits at $\mathbf{3 5}$ days of age:}

Some carcass properties were studied, such as, blood, feather, intestinal, eaten innards, and eviscerated weight as affected by both of light colors and strains (Cobb and IR).

Olanrewaju, et al. (2015), found that cool LED 1 light bulbs showed higher carcass weight in comparison with ICD light bulbs $(P=0.000)$. There was no difference between LED light bulbs examined, and ICD, warm LED, and cool LED 2 light bulbs did not affect carcass weight.

The obtained results in Table (8) showed the pre-slaughter weight in control and treated groups of different light colors (white as control, blue and green) for Cobb and IR chicken strains.

Data in Table (8) revealed that there were highly significant differences $(P \leq$ 0.01) in the values of pre-slaughter weight between control group for white light and other two lights groups blue and green, on other hand, there were no significant differences in the values of pre-slaughter weight between Cobb and IR strains.

The highest mean value was recorded for Cobb strain in blue light $(2114 \pm 42.49$ $\mathrm{g})$, followed by green light (2018.2 \pm 44.43 g), while white light registered the least value (1978.4 $\pm 10.06 \mathrm{~g})$. Results indicated that the pre-slaughter weight in blue light was increased by $06.85 \%$ compared to white light as control group, while it was $2.01 \%$ in green light.

However, the highest mean value was recorded for IR strain in blue light (2222 \pm $46.32 \mathrm{~g})$, followed by green light (2056.2 \pm $71.44 \mathrm{~g}$ ), while white light registered the least value $(1997.2 \pm 7.83 \mathrm{~g})$. Results indicated that pre-slaughter weight in blue light was increased by $11.26 \%$ compared to white light group, while it was $2.95 \%$ in green light. So, the blue LED light was recommended for best preslaughter body weight.

Table (8): Some carcass traits as affected by light color and strains at $\mathbf{3 5}$ days of age.

\begin{tabular}{|c|c|c|c|c|c|c|c|c|}
\hline \multirow[b]{2}{*}{ Strains } & \multirow[b]{2}{*}{$\begin{array}{l}\text { Light } \\
\text { color }\end{array}$} & \multirow[b]{2}{*}{ No. } & \multicolumn{6}{|c|}{ Mean \pm SE } \\
\hline & & & $\begin{array}{c}\text { Pre- } \\
\text { slaughter } \\
\text { weight (g) }\end{array}$ & $\begin{array}{c}\text { Blood } \\
\text { weight }(g)\end{array}$ & $\begin{array}{l}\text { Feather } \\
\text { weight }(g)\end{array}$ & $\begin{array}{l}\text { Intestinal } \\
\text { weight (g) }\end{array}$ & $\begin{array}{c}\text { Eaten } \\
\text { innards } \\
\text { weight }(g)\end{array}$ & $\begin{array}{c}\text { Eviscerated } \\
\text { weight }(g)\end{array}$ \\
\hline \multirow{3}{*}{ Cobb } & Green & 5 & $2018.2 \pm 44.43^{b}$ & $43.8 \pm 3.74^{\mathrm{ab}}$ & $77.8 \pm 9.39^{b}$ & $105.2 \pm 4.46^{a}$ & $113.4 \pm 3.05^{b}$ & $1561.6 \pm 37.59^{b}$ \\
\hline & Blue & 5 & $2114 \pm 42.49^{a}$ & $45.8 \pm 2.30^{a}$ & $72.6 \pm 9.53^{b}$ & $118 \pm 5.16^{a}$ & $121 \pm 2.39^{a}$ & $1636.4 \pm 44.32^{a}$ \\
\hline & White & 5 & $1978.4 \pm 10.06^{b}$ & $37.2 \pm 1.50^{b}$ & $98 \pm 3.81^{a}$ & $99.8 \pm 2.79^{a}$ & $110.4 \pm 1.89^{b}$ & $1525.4 \pm 9.45^{b}$ \\
\hline \multirow{3}{*}{ IR } & Green & 5 & $2056.2 \pm 71.44^{b}$ & $45 \pm 3.55^{\mathrm{ab}}$ & $81.4 \pm 9.53^{b}$ & $124.2 \pm 8.41^{a}$ & $120.6 \pm 7.53^{b}$ & $1563.6 \pm 65.74^{b}$ \\
\hline & Blue & 5 & $2222 \pm 46.32^{a}$ & $48.2 \pm 1.99^{a}$ & $74 \pm 1.05^{b}$ & $133.8 \pm 2.18^{a}$ & $135.2 \pm 4.68^{a}$ & $1707.4 \pm 49.57^{a}$ \\
\hline & White & 5 & $1997.2 \pm 7.83^{b}$ & $43.8 \pm 1.24^{b}$ & $100.8 \pm 0.86^{a}$ & $129.6 \pm 6.78^{a}$ & $128.6 \pm 2.63^{b}$ & $1477.2 \pm 11.99^{b}$ \\
\hline \multicolumn{9}{|c|}{ ANOVA } \\
\hline $\begin{array}{l}\text { Strains } \\
\text { (S) }\end{array}$ & \multicolumn{2}{|c|}{ P-Value } & $0.131^{\text {n.s }}$ & $0.117^{\text {n.s }}$ & $0.684^{\text {n.s }}$ & $0.001^{\star \star}$ & $0.001^{\star \star}$ & $0.809 \mathrm{n} . \mathrm{s}$ \\
\hline $\begin{array}{l}\text { Light } \\
\text { colors(C) }\end{array}$ & \multicolumn{2}{|c|}{ P-Value } & $0.001^{* *}$ & $0.056^{\star}$ & $0.002^{\star *}$ & $0.076^{\text {n.s }}$ & $0.033^{\star}$ & $0.001^{* *}$ \\
\hline$S \times C$ & \multicolumn{2}{|c|}{ P-Value } & $0.560^{\text {n.s }}$ & $0.550^{\mathrm{n} . \mathrm{s}}$ & $0.987^{\text {n.s }}$ & $0.411^{n . s}$ & $0.420^{n . s}$ & $0.369 n . s$ \\
\hline
\end{tabular}

a, b, c, :Means in the same column bearing different superscripts are significantly different .

** highly significant differences at $\mathbf{P} \leq 0.01$.

* significant differences at $P \leq 0.05$. 
Olanrewaju, et al. (2015), mentioned that cool LED 1 light bulbs showed higher live weight in comparison with ICD light bulbs $(P=0.019)$. However, there was no difference between LED light bulbs examined, and there was no difference in treatment effect between ICD, warm LED, and cool LED 2 light bulbs on live weight.

Recently, Simsek, et al. (2020), found that live weight gain was also different among the groups in the period of $1-35$ days. Green light group showed better performance in live weight gain than day light and blue light $(P \leq 0.01)$.

Results in Table (8) showed the blood weight in control and treated groups of different light colors (white as control, blue and green) for Cobb and IR chicken strains.

Data in Table (8) revealed that there were significant differences $(P \leq 0.05)$ in the values of blood weight between control group for white light and other two lights groups blue and green, on other hand, there were no significant differences in the values of blood weight between Cobb and IR strains.

The highest mean value was recorded for Cobb strain in blue light $(45.8 \pm 2.30$ $\mathrm{g})$, followed by green light $(43.8 \pm 3.74 \mathrm{~g})$, while white light registered the least value $(37.2 \pm 1.50 \mathrm{~g})$. Results indicated that the blood weight in blue light was increased by $23.12 \%$ compared to white light as control group, while it was $\mathbf{1 7 . 7 4}$ $\%$ in green light.

However, the highest mean value was recorded for IR strain in blue light (48.2 \pm $1.99 \mathrm{~g}$ ), followed by green light (45 \pm 3.55 g), while white light registered the least value $(43.8 \pm 1.24 \mathrm{~g})$. Results indicated that blood weight in blue light was increased by $10.05 \%$ compared to white light group, while it was $2.74 \%$ in green light.
The obtained results indicated that for blood weight represented about 2.17, 2.17 and $1.88 \%$ of the per slaughter weight for green, blue and white light respectively. But, for IR strain could be $2.19,2.17$ and $2.19 \%$ for green, blue and white light respectively.

Results in Table (8) showed the feather weight in control and treated groups of different light colors (White as control, blue and green) for Cobb and IR chicken strains.

The statistical analysis of the data in Table (8) revealed that there were highly significant differences $(P \leq 0.01)$ in the values of feather weight between control group for white light and other two lights groups blue and green, on other hand, there were no significant differences in the values of feather weight between Cobb and IR strains.

The highest mean value was recorded for Cobb strain in white light $(98 \pm 3.81 \mathrm{~g})$, followed by green light $(77.8 \pm 9.39 \mathrm{~g})$, while blue light registered the least value $(72.6 \pm 9.53 \mathrm{~g})$. Results indicated that the feather weight in green light was decreased by $20.61 \%$ compared to white light as control group, while it was $25.92 \%$ in blue light.

However, the highest mean value was recorded for IR strain in white light (100.8 $\pm 0.86 \mathrm{~g}$ ), followed by green light $(81.4 \pm 9.53 \mathrm{~g})$, while blue light registered the least value $(74 \pm 1.05 \mathrm{~g})$. Results indicated that feather weight in green light was decreased by $19.25 \%$ compared to white light group, while it was $26.59 \%$ in blue light.

The obtained results indicated that for feather weight represented about 3.85, 3.43 and $4.95 \%$ of the pre-slaughter weight for green, blue and white light respectively. But, for IR strain could be $3.96,3.33$ and $5.05 \%$ for green, blue and white light respectively. 
Nissa, et al. (2018), reported that no significant difference was observed among the different treatment groups for blood loss, feather loss, eviscerated yield and dressing yields and giblet yields.

Results in Table (8) showed the intestinal weight in control and treated groups of different light colors (white as control, blue and green) for Cobb and IR chicken strains.

Data in Table (8) revealed that there were no significant differences in the values of intestinal weight between control group for white light and other two lights groups blue and green. On other hand, there were highly significant differences $(P \leq 0.01)$ in the values of intestinal weight between Cobb and IR strains.

The highest mean value was recorded for Cobb strain in blue light (118 \pm 5.16 g), followed by green light (105.2 \pm 4.46 g), while white light registered the least value $(99.8 \pm 2.79 \mathrm{~g})$. Results indicated that the intestinal weight in blue light was increased by $18.24 \%$ compared to white light as control group, while it was $5.41 \%$ in green light.

However, the highest mean value was recorded for IR strain in blue light (133.8 $\pm 2.18 \mathrm{~g}$ ), followed by white light (129.6 \pm $6.78 \mathrm{~g}$ ), while green light registered the least value $(124.2 \pm 8.41 \mathrm{~g})$. Results indicated that intestinal weight in blue light was increased by $3.24 \%$ compared to white light group, while it was decreased by $4.17 \%$ in green light.

The obtained results indicated that for intestinal weight represented about 5.21, 5.58 and $5.04 \%$ of the live weight for green, blue and white light respectively. But, for IR strain weighed 6.04, 6.02 and $6.49 \%$ for green, blue and white light respectively.

Results in Table (8) showed the eaten innards weight in control and treated groups of different light colors (white as control, blue and green) for Cobb and IR chicken strains.

Data in Table (8) revealed that there were significant differences $(P \leq 0.05)$ in the values of eaten innards weight between control group for white light and other two lights groups blue and green, on other hand, there were highly significant differences $(P \leq 0.01)$ in the values of eaten innards weight between Cobb and IR strains.

The highest mean value was recorded for Cobb strain in blue light $(121 \pm 2.39 \mathrm{~g})$, followed by green light $(113.4 \pm 3.05 \mathrm{~g})$, while white light registered the least value $(110.4 \pm 1.89 \mathrm{~g})$. Results indicated that the eaten innards weight in blue light was increased by $9.60 \%$ compared to white light as control group, while it was $2.72 \%$ in green light.

However, the highest mean value was recorded for IR strain in blue light $(135.2 \pm 4.68 \mathrm{~g})$, followed by white light $(128.6 \pm 2.63 \mathrm{~g})$, while green light registered the least value $(120.6 \pm 7.53 \mathrm{~g})$. Results indicated that eaten innards weight in blue light was increased by $\mathbf{5 . 1 3}$ $\%$ compared to white light group, while it was decreased by $6.22 \%$ in green light.

The obtained results indicated that eaten innards weight represented about $5.62,5.72$ and $5.58 \%$ of the live weight for green, blue and white light respectively. But, for IR strain were 5.87, 6.08 and $6.44 \%$ for green, blue and white light respectively.

Mohamed, et al. (2014), indicated that the weight of the liver, spleen and bursa of Fabricius in broilers reared under white light was significantly higher ( $P \leq$ 0.05) than blue light.

Yang, et al. (2016), observed that no significant differences were found for the heart, the spleen, or the liver weight between the birds treated with a single 
treatment ( $G$ and $B$ groups) or mixed lights treatment ( $G-B$ and $G \times B$ groups) and the birds with normal artificial lights treatment $(P=0.256)$. However, the birds treated with the G-B group had the greater heart and spleen weights than $B$ group $(P=0.026$ and 0.031$)$. The birds treated with the G-B group and $G \times B$ group had the greater gizzard weight than $G$ group ( $P=0.011$ and 0.0019 ). Additionally, no significant differences either between G-B group and $G \times B$ group either in the heart, the spleen, the liver weight, or the stomach weights $(P=$ 0.167).

Data in Table (8) revealed that there were highly significant differences $(P \leq$ 0.01 ) in the values of eviscerated weight between control group for white light and other two lights groups blue and green. On other hand, there were no significant differences in the values of eviscerated weight between Cobb and IR strains.

The highest mean value was recorded for Cobb strain in blue light (1636.4 \pm 44.32 g), followed by green light (1561.6 \pm 37.59 g), while white light registered the least value $(1525.4 \pm 9.45 \mathrm{~g})$. Results indicated that the eviscerated weight in blue light was increased by $7.28 \%$ compared to white light as control group, while it was $2.37 \%$ in green light.

Also, the highest mean value was recorded for IR strain in blue light $(1707.4 \pm 49.57 \mathrm{~g})$, followed by green light $(1563.6 \pm 65.74 \mathrm{~g})$, while white light registered the least value $(1477.2 \pm 11.99$ g). Results indicated that eviscerated weight in blue light was increased by $15.58 \%$ compared to white light group, while it was $5.85 \%$ in green light.

The results in Table (9) indicated that dressing percentages were represented about $77.38,77.41$ and $77.10 \%$ of the preslaughter weight for green, blue and white light respectively, for Cobb strain. But, for IR strain could be 76.04, 76.84 and $73.96 \%$ for green, blue and white light respectively.

Obtained results were in agreement with those found by Almeida, et al. (2015) and Olanrewaju, et al. (2018).

Table (9): Dressing percentage (\%) as affected by light colors and strains at 35 days of age.

\begin{tabular}{|c|c|c|c|}
\hline Strains & Light colors & $\mathbf{n}$ & Dressing percentage (\%) \\
\hline \multirow{3}{*}{ Cobb } & Green & 5 & $77.38 \pm 0.33^{\mathrm{a}}$ \\
\cline { 2 - 4 } & Blue & 5 & $77.41 \pm 0.33^{\mathrm{a}}$ \\
\cline { 2 - 4 } & White & 5 & $77.10 \pm 0.33^{\mathrm{b}}$ \\
\hline \multirow{3}{*}{ IR } & Green & 5 & $76.04 \pm 0.33^{\mathrm{b}}$ \\
\cline { 2 - 4 } & Blue & 5 & $76.84 \pm 0.33^{\mathrm{a}}$ \\
\cline { 2 - 4 } & White & 5 & $73.96 \pm 0.33^{\mathrm{c}}$ \\
\hline \multicolumn{4}{|c|}{ ANOVA } \\
\hline Strains (S) & P-Value & $0.012^{\star}$ & \\
\hline Light colors (C) & P-Value & $0.001^{\star \star}$ & \\
\hline S×C & P-Value & $0.045^{\star}$ & \\
\hline
\end{tabular}

a, b, c, :Means in the same column bearing different superscripts are significantly different .

** significant differences at $P \leq 0.01$

* significant differences at $P \leq 0.05$

n.s. not significa 


\section{Conclusions}

It can be concluded that the blue LED light gave the highest body weight, dressing percentage, best feed conversion ratio, and the highest ratios of growth hormone and antibody titer concentration in Cobb and IR strains compared to green or white light under the same experimental conditions.

\section{REFERENCES}

Alattar, E., K. Elwasife and E. Radwan (2019). The Effect of Light-Emitting Diode Light on the Physical Traits of Chicks. Open Journal of Animal Sciences. 9:481-491.

Almeida, A. Z., I. M. T. D. Jacome, R. A. Tavares, R. G. Garcia, I. d. A.r Naas, F. R. Caldara, S. Sgavioli, B. Barreto and L. G. Rombola (2015). Effect of different led light colors on development of the reproductive system of quails. Inter. J. of Poult. Sci. 14 (7): 383-386

Borille R., R.G. Garcia, A.F.B. Royer, M.R. Santana, S. Colet, I.A. Naas, F.R. Caldara, I.C.L. Almeida Paz, E.S. Rosa and V.A.R. Castilho (2013). The use of light-emitting diodes (LED) in commercial layer production. Brazilian J. Poult. Sci. 15:135-140.

Cao J., Z. Wang, Y. Dong, Z. Zhang, J. Li, F. Li and Y. Chen (2012). Effect of combinations of monochromatic lights on growth and productive performance of broilers. Poultry Sci. 91 :3013-3018

Duncan, D. B. (1955). Multiple ranges and multiple F test. Biometrics (11):1-42.

Hesham, M.H., A.H El Shereen and S. N. Enas (2018). Impact of different light colors in behavior, welfare parameters and growth performance of Fayoumi broiler chickens strain. J. Hellenic Vet. Med Soc. 69(2): 951-958.

Iranmanesh, A., B. Grisso and J. D. Veldhuis (1994). Low basal and persistent pulsatile growth hormone secretion are revealed in normal and hyposomatotropic men studied with a new ultrasensitive chemiluminescence assay. J Clin Endocrinol Metab. 78: 526-535.

Khaliq, T., A. A. Khan, H. Hamadani, M. Shafi and M. T. Banday (2017). Economics of Broiler Rearing Under Different Colours of Light. International Journal of Livestock Research. 7(6): 58-62.

Kim, M. J., R. Parvin, M. M. H. Mushtaq, J. Hwangbo, J. H. Kim, J. C. Na, D. W. Kim, H. K. Kang, C. D. Kim, K. O. Cho, C. B. Yang and H. C. Choi (2013). Growth performance and hematological traits of broiler chickens reared under assorted monochromatic light sources. Poultry Sci. 92 :1461-1466

Kumar, S., R. K. Gupta, Y. Singh, A. Sharma and N. Kashyap (2019). Influence of coloured light on broiler bird performance. International Journal of Chemical Studies. 7(4): 2038-2041.

Kühn, E. R., V. M. Darras, Gysemans, Decuypere, Berghman and J. Buyse (1996). The use of intermittent lighting in broiler raising. 2. Effects on the Somatotrophic and Thyroid Axes and on Plasma Testosterone Levels. Poultry. Sci. 75: 589-594.

Mohamed, R. A., M. M. Eltholth and N. R. El-Saidy (2014). Rearing broiler chickens under monochromatic blue light improve performance and reduce fear and stress during pre-slaughter handling and transportation. Biotechnology in Animal Husbandry. 30 (3): 457-471.

Mudhar, A. S. A. T. (2016a). An Investigation on the Effect of Light Color and Stocking Density on Some Blood Parameters of Broilers and 
Layers. Donnish Journal of Agricultural Research. 3(2): 8-12.

Mudhar, A. S. A. T. (2016b). The Effect of Color Light and Stocking Density on Some Biochemical Traits of Broilers and Layers. Research in Zoology. 6(2): 21-28.

NRC (1994). Nutrients Requirements of poultry (7th rev.) Washington: Natl. Acad. Press. Washington. D.C.

Nissa, S. S., I.U. Sheikh, M.T. Banday, B. Zaffer, S. Shafiq, A. I. Qureshi, S. Shubeena and S. Mehboob (2018). Carcass characteristics of broiler chicken reared under different light sources. Journal of Entomology and Zoology Studies. 6(5): 396-399.

Olanrewaju, H. A., J. L. Purswell, W. R. Maslin, S. D. Collier and S. L. Branton (2015). Effects of color temperatures (kelvin) of LED bulbs on growth performance, carcass characteristics, and ocular development indices of broilers grown to heavy weights1. Poultry Sci. 94:338-344

Olanrewaju H. A., W. W. Miller, W. R. Maslin, S. D. Collier, J. L. Purswell, and S. L. Branton (2018). Influence of light sources and photoperiod on growth performance, carcass characteristics, and health indices of broilers grown to heavy weights ${ }^{2}$. Poultry Sci. Vol 97:1109-1116.

Siegel, P.B. and W.B. Gross (1980). Production and persistence of antibody response to sheep erythocytes. 1. Directional selection poultry Science, 59: 1-6.

Simsek, U.G., M.Ciftci, M. Yaman, M. Ozcelik, Y. Baykalir, A. Kizilaslan, A. Bayrakdar, Z. Cambay, S. Yakut and Z. Erisir (2020). Effects of light color on growth performance, histomorphometric features of small intestine and some blood parameters in chukar partridges (Alectoris chukar). Kafkas Univ Vet Fak Derg, 26 (1): 33-39.

SPSS Program (2004). User's guide statistic. Release 10.01, Copyright SPSS Inc., USA.

Wang, Y., W. Cao, B. Li, J. Ding and H. Yang (2016). Effects of exposure to monochromatic light on pigeon squab performance and growth-related hormones. Avian Biology Research 9 (3): 147-151

Xie, D., Z. Wang, J. Cao, Y. Dong and Y. Chen (2008a). Effects of monochromatic light on proliferation response of splenocyte in broilers. Anatomia, Histologia, Embryologia, 37: 332-337.

Xie, D., Z.X. Wang, Y.L. Dong, J. Cao, J.F. Wang, J.L. Chen and Y.X. Chen (2008b). Effects of monochromatic light on immune response of broilers. Poultry Sci., 87: 1535-1539.

Yang Y., Y. Yu, J. Pan, Y. Ying and $H$. Zhou. (2016). A new method to manipulate broiler chicken growth and metabolism: Response to mixed LED light system. Scientific Reports. 1-10.

Zhang, L., S. Wu, J. Wang, X. Qiao, H. Yue, J. Yao, H. Zhang and G. Qi (2014). Changes of Plasma Growth Hormone, Insulin-Like Growth Factors-I, Thyroid Hormones, and Testosterone Concentrations in Embryos and Broiler Chickens Incubated under Monochromatic Green Light. Italian Journal of Animal Science. 13:530535. 
تأثير استخدام لمبات الصمام الباعث للضوء الملونة علي بعض القياسات الفسيولوجية في سلالتين من كتاكيت اللحم

\author{
فاروق حسن عبده، عبد المنعم عبد الحليم الفقى، إيمان متولى أبو عليوه،

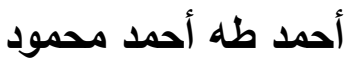

قسم إنتاج الدواجن والأسماك، كلية النزاعة بشبين الكوم، جامعة المنوفية.

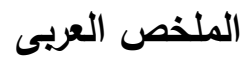

تناولت الدارسة الحالية إنتاج دجاج التسمين تحت ألوان ضوء LED وسلالات المختلفة. بالإضافة إلى دراسة

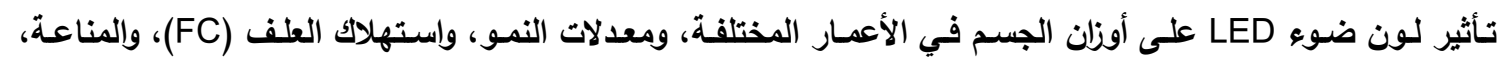

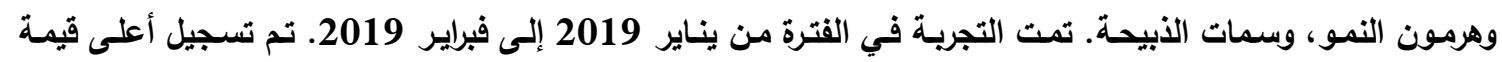

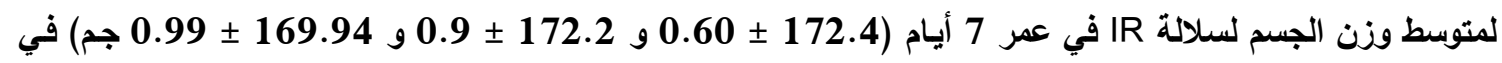

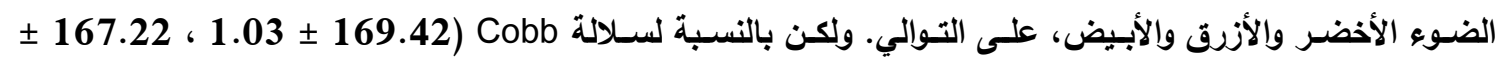

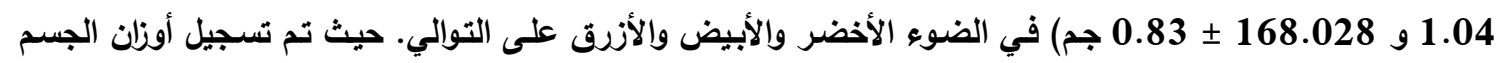

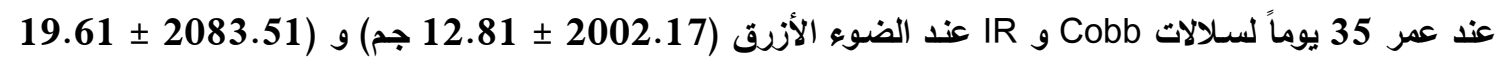

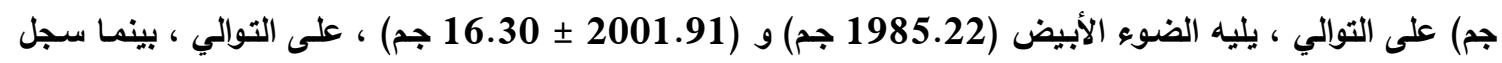

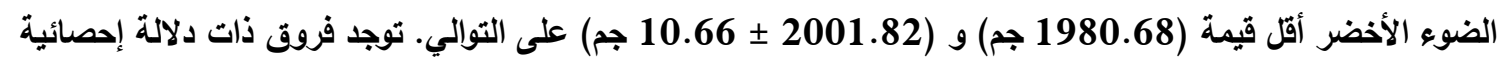

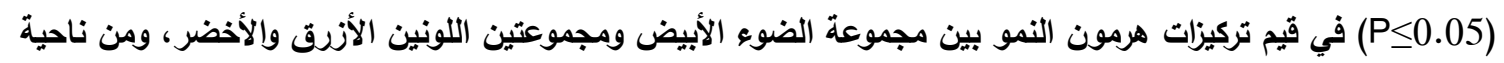

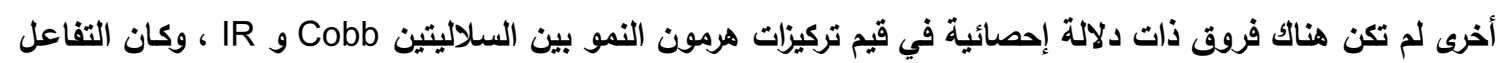

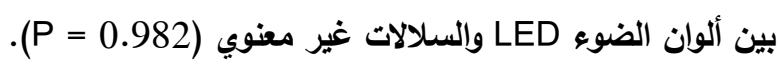

